\title{
Dual role of CCL3/CCR1 in oral squamous cell carcinoma: Implications in tumor metastasis and local host defense
}

\author{
TARCíLIA APARECIDA SILVA ${ }^{1}$, FERNANDA LUIZA LEITE RIBEIRO ${ }^{2}$, \\ HELENISA HELENA DE OLIVEIRA-NETO ${ }^{2}$, SATIRO WATANABE ${ }^{2}$, \\ RITA DE CáSSIA GONÇALVES ALENCAR ${ }^{3}$, SANDRA YASUYO FUKADA ${ }^{4}$, \\ FERNANDO QUEIROZ CUNHA ${ }^{4}$, CLáUDIO RODRIGUES LELES ${ }^{2}$, \\ ELISMAURO FRANCISCO MENDONÇA ${ }^{2}$ and ALINE CARVALHO BATISTA ${ }^{2}$
}

\begin{abstract}
${ }^{1}$ Department of Oral Surgery and Pathology, Dental School, Federal University of Minas Gerais, Belo Horizonte, CEP 31270-217; ${ }^{2}$ Department of Stomatology (Oral Pathology), Dental School, Federal University of Goiás, Goiânia, CEP 74605-220; ${ }^{3}$ Anatomopathology and Cytopathology Division of Araújo Jorge Hospital, Association of Cancer Combat of Goiás, Goiânia, CEP 74605-220; ${ }^{4}$ Department of Pharmacology, School of Medicine of Ribeirão Preto, Universidade de São Paulo, Ribeirão Preto, São Paulo, Brazil
\end{abstract}

Received June 22, 2007; Accepted July 31, 2007

\begin{abstract}
Chemokines are small chemotactic cytokines that can induce the migration of leukocytes, activate inflammatory/immune responses and have recently been implicated in the regulation of tumor growth and organspecific spread. In this setting, the macrophage inflammatory protein-1 $\alpha$ (CCL3) chemokine displays a diversity of roles that may contribute to the directional migration of squamous cells into cervical lymph nodes or to the defense against tumor initiation and progression. Thus, the aim of this study was to determine, for the first time, the expression of CCL3 and their receptors, CCR 1 and CCR5, by real-time polymerase chain reaction in samples obtained from oral squamous cell carcinoma (OSCC) and healthy gingival tissue (control). In addition, we investigated the immunoexpression of these molecules in neoplastic cells (parenchyma), inflammatory/immune cells (stroma) in primary OSCC and in metastatic and non-metastatic lymph node tissues. The relationship of CCL3/CCR1 with survival data was also evaluated. The analysis of mRNA expression revealed a significantly higher expression of CCL3 and CCR1 in OSCC compared with the controls $(\mathrm{P}<0.05)$. The expression of CCR5 was not different in the two groups. The percentages of $\mathrm{CCL}^{+}$and $\mathrm{CCR}^{+}$cells were observed to be similar in
\end{abstract}

Correspondence to: Dr Aline Carvalho Batista, Rua 55, Quadra B-7, Lote 11/12, N. 88, Apto 1003, Edifício Antônio Miranda, Jardim Goiás, Goiânia-GO CEP 74810-230, Brazil

E-mail: ali.caba@uol.com.br

Key words: macrophage inflammatory protein-1 $\alpha$, CCR1, CCR5, chemokine, oral squamous cell carcinoma, metastasis, lymph node parenchyma and stroma in the OSCC without lymph node metastasis when compared with OSCC with lymph node metastasis $(\mathrm{P}>0.05)$. However, we observed the density of $\mathrm{CCL}^{+}$nodal cells to be significantly higher in metastatic lymph nodes when compared with non-metastatic lymph nodes in the same patients $(\mathrm{P}<0.05)$. Considering CCL3 in stroma, the mean survival rate for patients with high $\mathrm{CCL}^{+}$ cell percentage was better than for those with low $\mathrm{CCL}^{+}$cell percentage. Our findings suggest that the CCL3/CCR1 axis may have a role in the spread of tumoral cells to the lymph nodes and also in the local host defense against the tumor.

\section{Introduction}

Chemokines are a large family of small structurally-related heparin-binding proteins that have been identified as attractants of blood leukocytes to sites of infection and inflammation, and are induced by inflammatory cytokines, growth factors and pathogenic stimuli $(1,2)$. Directed migration of cells that express the appropriate chemokine receptor occurs along a chemical gradient of ligand allowing cells to move towards high local concentrations of chemokines $(1,3)$. Although originally identified on leukocytes, functional chemokines and chemokine receptors are also found on neoplastic cells (3) and on tumor-associated stromal cells (3). In this setting, the formation of metastasis shares many similarities with leukocyte trafficking, a process critically regulated by chemokines and their receptors (3-6). Recent studies have demonstrated that the expression of chemokines are associated with the process of metastasis $(6,7-9)$. Therefore, neutralizing interactions of CXCR4/CXCL12 impairs metastasis of breast cancer cells (8).

In oral cancer, especially in OSCC, some studies indicate that the chemokine stromal-cell-derived factor-1 $\alpha$ (SDF$1 \alpha /$ CXCL12) and its receptor, CXCR4, might be involved in the establishment of lymph node metastasis and invasion at the 
primary site (10-13). Muller et al (6) demonstrated that CCR7 and CXCR5 were consistently expressed in squamous cell carcinoma, while CXCR4 demonstrates negligible levels in this tumor.

Previously, the chemokine, macrophage inflammatory protein-1 $\alpha /$ CCL3, and its receptor, CCR1, were demonstrated to be aberrantly expressed in human hepatocellular carcinoma tissues (14). Furthermore, Yang et al (15), in 2006, demonstrated an important contribution of the CCR1-CCL3 axis to hepatocellular carcinoma progression. Conversely, CCL3 is a member of the CC chemokine subfamily that is thought to regulate the recruitment of monocytes/ macrophages, through its binding to CCR 1 and CCR5 receptors, as well as their activation, contributing to the tumoricidal activity of these cells (16). The in vitro profile of activity of CCL3 in chemotaxis assays includes effects on activated T lymphocytes, NK cells, dendritic cells, eosinophils, neutrophils and mast cells (17-24). Thus, the regulation of immunocompetent cell migration and the driving of the TH1 response by CCL3 suggest that this chemokine may participate in the host's anti-tumor responses (16). Consistent with this, tumor cells transfected with the CCL3 gene have reduced tumorigenicity and are able to induce anti-tumor immunity (25).

Controversy surrounds the role of CCL3 in tumorigenesis in that it has not been defined whether this chemokine is associated with tumor progression or contributes to the defense against malignant tumors. In this study, we investigated the expression of CCL3 and its receptors, CCR 1 and CCR5, in primary OSCC samples and lymph node tissues, and evaluated their relationship with clinicopathological factors, including survival data and lymph node metastasis.

\section{Materials and methods}

Real-time polymerase chain reaction (RT-PCR). This study was approved by the institutional ethics committee for human subjects. Samples from twelve patients' with primary OSCC ( 8 males and 4 females, age range from $42-85$ years with a median of 60.8 years) were collected at the Oral Disease Center of Goiás State of Dental School of the Federal University of Goiás for RT-PCR. All the patients had a history of chronic cigarette consumption and this was associated with alcohol consumption in seven. The OSCC lesions had Stage III-IV disease (UICC). The control group comprised of five samples of clinically healthy gingival collected during third molar removal. The samples obtained from patients were divided in two equal parts. Half of each specimen was immersed in Trizol reagent (Gibco BRL, Life Technologies, Rockville, MD, USA) and stored at $-20^{\circ} \mathrm{C}$. The second half was fixed in neutral buffered formalin, embedded by a routine technique in paraffin wax and sectioned at $5 \mu \mathrm{m}$ for hematoxylin and eosin staining.

Complementary DNA (cDNA) was synthesized using $2 \mu \mathrm{g}$ of RNA through a reverse transcription reaction (Superscript II, Gibco). Real-time PCR quantitative mRNA analyses were performed in an ABI Prism 5700 Sequence Detection System using the SYBR-Green fluorescence quantification system (Applied Biosystems, Warrington, UK) for quantitation of amplicons. The standard PCR conditions were $95^{\circ} \mathrm{C}(10 \mathrm{~min})$, and then 40 cycles of $94^{\circ} \mathrm{C}(1 \mathrm{~min}), 56^{\circ} \mathrm{C}(1 \mathrm{~min})$ and $72^{\circ} \mathrm{C}$
( 2 min), followed by the standard denaturation curve. The primer sequences, the predicted amplicon sizes and melting temperatures $(\mathrm{Mt})$ used were as follows: $\beta$-actin sense, ATGTTTGAGACCTTCAACAC; antisense, CACGTCAC ACTTCATGATGG, resulting in a 495 base-pair (bp) amplification product; CCL3 sense, CTCTGCATCACTTG CTGCTGACAC; antisense, GTCAGCGACCTGGAGCTG AGTG (212 bp, Mt 68 ${ }^{\circ}$ ); CCR1 sense, CCTTCTGGATCG ACTACAAGTT; antisense, GTAGCAGATGATCATGAC CAAC (396 bp, Mt 64 ${ }^{\circ}$ ); CCR5 sense, CTCTTCCTGCTC ACACTACCAT; antisense, TGTGTAGAAAATGAGGAC TGCA (322 bp, Mt $72^{\circ} \mathrm{C}$ ). PCR conditions for each target were conscientiously optimized with regard to primer concentration, absence of primer dimer formation, and efficiency of amplification of target genes and housekeeping gene control. SYBR-Green PCR Master Mix (Applied Biosystems). The threshold for positivity of real-time PCR was determined based on negative controls. The relative levels of gene expression were calculated by reference to the $B$-actin in the sample, using the cycle threshold $(\mathrm{Ct})$ method. The mean $\mathrm{Ct}$ values from duplicate measurements were used to calculate expression of the target gene, with normalization to $\beta$-actin and then compared with the target-internal control in control subjects to calculate fold-increase expression, using the $2-\Delta \mathrm{Ct}$ formula. Negative controls without RNA and without reverse transcriptase were also performed. The results show one experiment representative of three.

\section{Immunohistochemistry}

Patient population. Our patient population consisted of 43 patients with primary OSCC, where $22(51.2 \%)$ patients had oral tumors without cervical lymph node metastasis and 21 $(48.8 \%)$ patients had oral tumors with cervical lymph node metastasis. All the patients in this study were submitted to surgical treatment consisting of cervical lymph node removal with microscopic evaluation and none received radiotherapy, chemotherapy or any other treatment prior to surgery. Clinical data (gender, age, ethnic group, tobacco and alcohol consumption, tumor location, extension, $\mathrm{T}$ and $\mathrm{N}$ stages) and follow-up information (recurrence and death) were obtained from medical records. The main clinical features of our series of 43 patients with OSCC are summarized in Table I.

Samples. Surgically-excised specimens of primary OSCC were obtained from the files of the Anatomopathology and Cytopathology Division of Araújo Jorge Hospital, Association of Cancer Combat of Goiás, Goiânia, Brazil. Of the patients with cervical lymph node metastasis $(n=21)$, samples were obtained from $48 \%(n=10)$ of both lymph node with metastasis (positive) and lymph node without metastasis (negative). In addition, samples of the lymph nodes $(n=7)$ were taken from the patients with oral tumor but without cervical lymph node metastasis (negative).

Light microscopy. All specimens were fixed in $10 \%$ buffered formalin ( $\mathrm{pH} \mathrm{7.4)} \mathrm{and} \mathrm{paraffin-embedded.} \mathrm{The} \mathrm{microscopic}$ features were evaluated from the analysis of one $5 \mu \mathrm{m}$ section of each sample, stained routinely with hematoxylin and eosin (H.E.). All the sections were examined by light microscopy to confirm the presence or not of lymph node metastasis and to characterize the OSCC. 
Table I. Main clinical findings of patients with OSCC $(n=43)$.

\begin{tabular}{|c|c|c|c|}
\hline Clinical features & & Number of cases & $\%$ \\
\hline Age & $\begin{array}{l}\leq 65 \text { years } \\
>65 \text { years }\end{array}$ & $\begin{array}{l}26 \\
17\end{array}$ & $\begin{array}{l}60.5 \\
39.5\end{array}$ \\
\hline Gender & $\begin{array}{c}\text { Male } \\
\text { Female }\end{array}$ & $\begin{array}{l}30 \\
13\end{array}$ & $\begin{array}{l}69.8 \\
30.2\end{array}$ \\
\hline Ethnic group & $\begin{array}{c}\text { Caucasian } \\
\text { Non-caucasian }\end{array}$ & $\begin{array}{l}27 \\
16\end{array}$ & $\begin{array}{l}62.8 \\
37.2\end{array}$ \\
\hline Location & $\begin{array}{c}\text { Oral tongue } \\
\text { Floor of the mouth } \\
\text { Others }\end{array}$ & $\begin{array}{l}17 \\
14 \\
12\end{array}$ & $\begin{array}{l}39.5 \\
32.6 \\
27.9\end{array}$ \\
\hline Tobacco & $\begin{array}{l}\text { Yes } \\
\text { No }\end{array}$ & $\begin{array}{c}37 \\
6\end{array}$ & $\begin{array}{l}86 \\
14\end{array}$ \\
\hline Alcohol & $\begin{array}{l}\text { Yes } \\
\text { No }\end{array}$ & $\begin{array}{l}29 \\
14\end{array}$ & $\begin{array}{l}67.4 \\
32.6\end{array}$ \\
\hline T stage & $\begin{array}{l}\mathrm{T} 1-\mathrm{T} 2 \\
\mathrm{~T} 3-\mathrm{T} 4\end{array}$ & $\begin{array}{c}7 \\
36\end{array}$ & $\begin{array}{l}16.3 \\
83.7\end{array}$ \\
\hline Clinical outcome $(n=43)$ & $\begin{array}{c}\text { Dead } \\
\text { Alive (overall survival) }\end{array}$ & $\begin{array}{l}15 \\
28\end{array}$ & $\begin{array}{l}26 \\
58\end{array}$ \\
\hline Survival time $(\mathrm{n}=43)$ & $\begin{array}{l}\text { Alive: } \geq 36 \text { months } \\
\text { Alive: }<36 \text { months }\end{array}$ & $\begin{array}{l}21 \\
22\end{array}$ & $\begin{array}{l}48.8 \\
51.2\end{array}$ \\
\hline
\end{tabular}

Immunohistochemistry technique. Paraffin-embedded tissues were sectioned $(3 \mu \mathrm{m})$ and collected in serial sections on glass slides coated with $2 \%$ of 3-aminopropyltriethylsilane (SigmaAldrich, St. Louis, MO). The sections were deparaffinized by immersion in xylene and this was followed by immersion in alcohol and then incubation with $3 \%$ hydrogen peroxide diluted in Tris-buffered saline (TBS) $(\mathrm{pH} \mathrm{7.4)}$ for $40 \mathrm{~min}$. The sections were immersed in citrate buffer ( $\mathrm{pH}$ 6.0; Sigma, $\mathrm{P} 4809$ ) for $20 \mathrm{~min}$ at $95^{\circ} \mathrm{C}$ for antigen retrieval, then blocked by incubation with $3 \%$ normal goat serum diluted in distilled water, at room temperature, for $20 \mathrm{~min}$. The slides were incubated with the following primary antibodies: rabbit antihuman CCL3 (FL-92) polyclonal antibody (SC-33203, Santa Cruz Biotechnology, Santa Cruz, CA) at 1:200; goat antihuman CCR1 (C-20) polyclonal antibody (SC-6125, Santa Cruz) at $1: 100$, at $4^{\circ} \mathrm{C}$ overnight in a humidified chamber.

After washing in TBS, the sections were treated with the labeled streptavidin-biotin (LSAB kits (K0492), Dako, Carpinteria, CA). The sections were then incubated in 3,3'diaminobenzidine (DAB) in a chromogen solution (K3468, Dako) for 2 to $5 \mathrm{~min}$ at room temperature. Finally, the sections were stained with Mayer's hematoxylin and were covered. Negative controls were obtained by the omission of primary antibodies, which were substituted by $1 \%$ PBS-BSA and by non-immune rabbit (X0902, Dako) or goat (X501-1, Dako) serum. Inflammatory cells represented an internal positive control for CCL3 and CCR1 immunostaining.

Cell counting and statistical analysis. The relative proportions of $\mathrm{CCL}^{+}$and $\mathrm{CCR} 1^{+}$cells in primary OSCC were determined separately in epithelial neoplastic cells (parenchyma) and in the region adjacent to the tumor front area of OSCC (stroma). All counts were performed in 10 consecutive microscopic high power fields (x1000) using an integration graticule (4740680 000000-Netzmikrometer 12.5x, Carl Zeiss, Göttingen, Germany). The percentage of positive cells was calculated as the proportion of the total of the neoplastic (parenchyma)/ inflammatory (stroma) cells. The cell proportions were expressed as percentages (mean $\pm \mathrm{SD}$ ). A P-value of $<0.05$ was considered to be statistically significant. The location and distribution of $\mathrm{CCL}^{+}$and $\mathrm{CCR} 1^{+}$cells were also analyzed.

Two OSCC groups were established: group I patients with oral tumor but without cervical lymph node metastasis $(n=22)$ and group II patients with cervical lymph node metastasis $(n=21)$; the comparative analyses of the densities of CCL $3^{+}$ and $\mathrm{CCR} 1^{+}$cells between these two groups were performed using the non-parametric Mann-Whitney test.

In lymph node samples, the numbers of $\mathrm{CCL}^{+}$and $\mathrm{CCR} 1^{+}$ lymph node cells (nodal cells) and metastatic tumor cells were calculated per $\mathrm{mm}^{2}$ using an integration graticule (Carl Zeiss). The positive cells were enumerated in 10 representative microscopic high-power fields (x400) and at this magnification, each field (integration graticule) had an area of $0.0961 \mathrm{~mm}^{2}$. The analyses were expressed as mean \pm standard deviation (SD) of $n$ observations, per $\mathrm{mm}^{2}$.

Comparative analyses of the numbers of $\mathrm{CCL}^{+}$and $\mathrm{CCR} 1^{+}$ lymph node cells (nodal cells) per $\mathrm{mm}^{2}$ between metastatic lymph nodes and non-metastatic lymph nodes in the same patients were performed using the parametric Wilcoxon Signed Ranks test. The comparative evaluation of the number of $\mathrm{CCL}^{+}{ }^{+}$and $\mathrm{CCR} 1^{+}$nodal cells between metastatic lymph nodes of patients with metastasis and non-metastatic lymph nodes of 

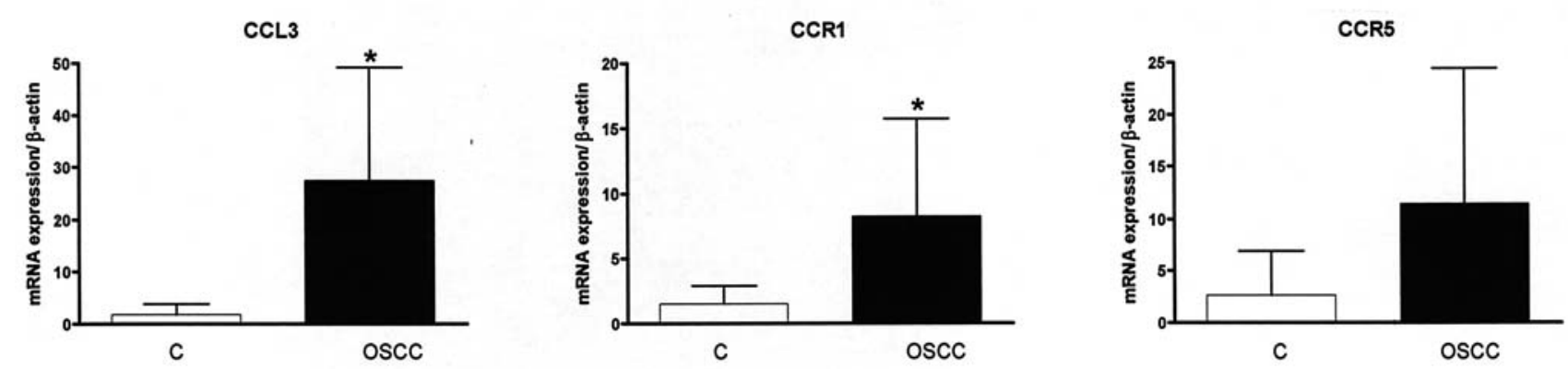

Figure 1. Expression of CCL3 and its receptors, CCR1 and CCR5, in primary oral squamous cell carcinoma (OSCC) and healthy gingival tissues (control). Total RNA was extracted and the expressions of CCL3, CCR1 and CCR5 were analyzed by real-time PCR. The mRNA expression was quantified as its ratio to $ß$-actin. ${ }^{*} \mathrm{P}<0.05$ compared to controls.

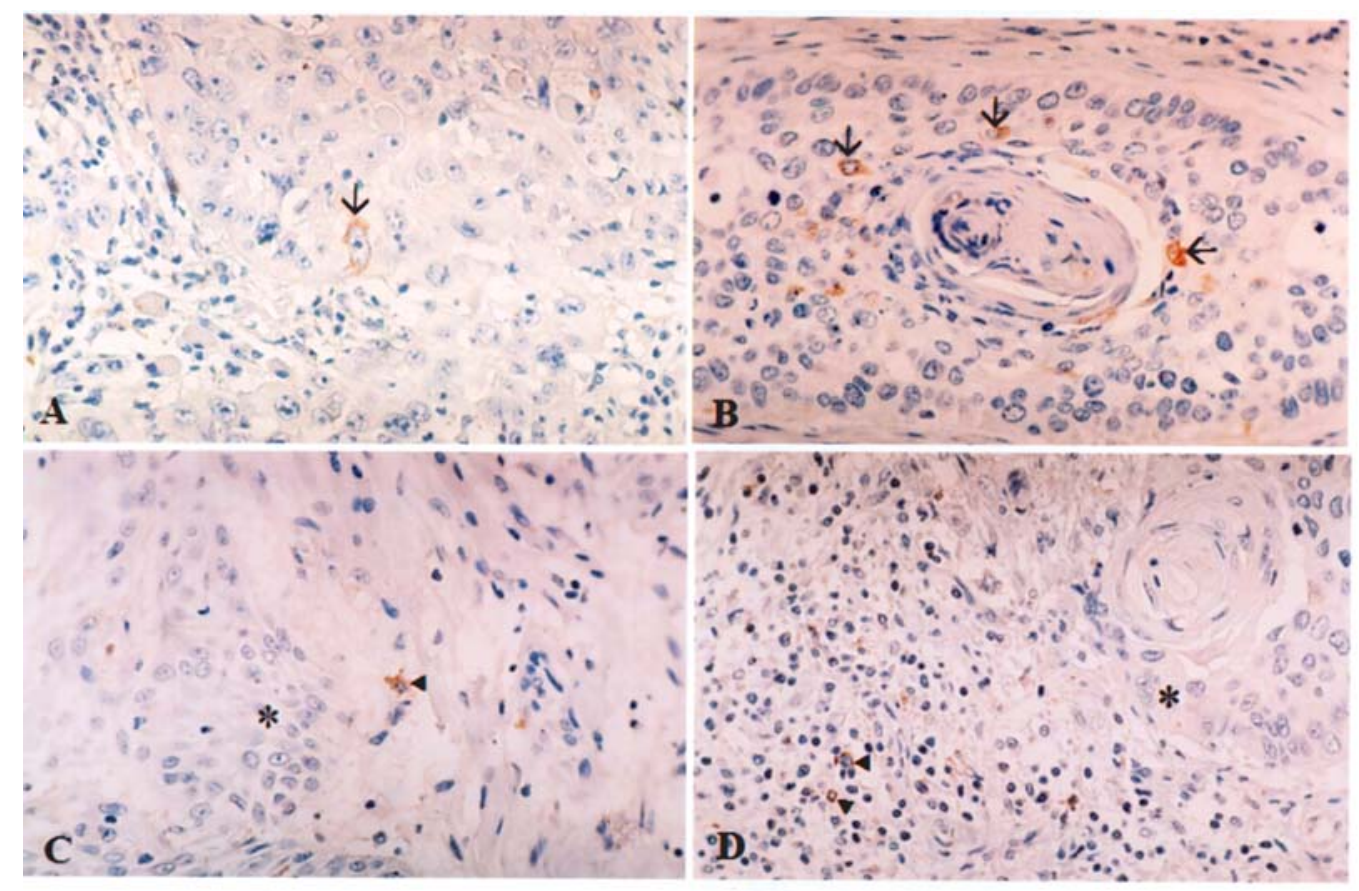

Figure 2. Expression of CCL3 (A) and CCR1 (B) by neoplastic cells (arrows) of primary oral squamous cell carcinoma (OSCC) and expression of CCL3 (C) and CCR1 (D) by stromal cells (arrowheads) close to tumoral cells (asterisks). Immunohistochemical staining, original magnification x400 (A-D).
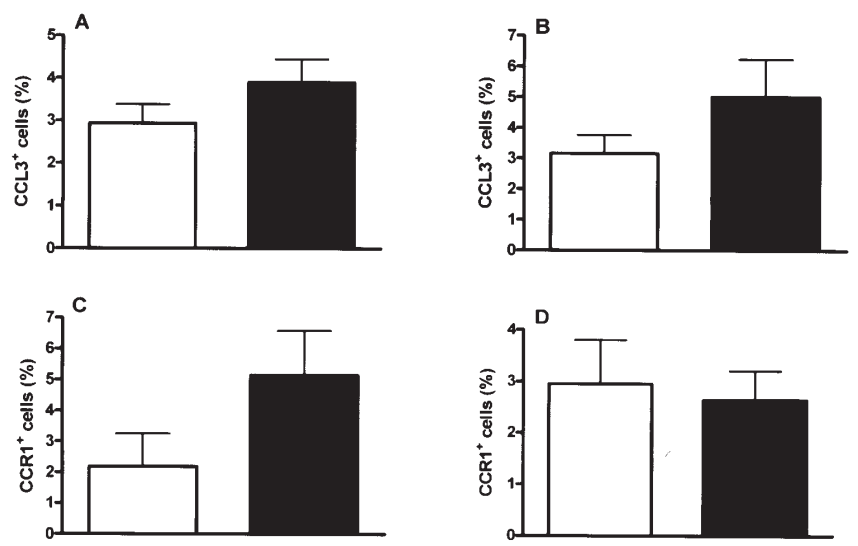

Figure 3. Densities of CCL3 (A and B) and CCR1 (C and D) positive cells in parenchyma ( $\mathrm{A}$ and $\mathrm{C}$ ) and stroma $(\mathrm{B}$ and $\mathrm{D})$ of primary oral squamous cell carcinoma (OSCC) of patients without metastasis (white bars) and patients with metastasis (black bars). Results are expressed as the mean percentages of CCL3 and CCR1 positive cells \pm SD. patients without lymph node metastasis were performed using the non-parametric Mann-Whitney test.

The influence of tumor-associated CCL3 and CCR 1 on the prognosis of OSCC patients was evaluated by the KaplanMeier test. The survival rate was calculated from surgical resection until their last follow-up appointment or the death of the patient. CCL3 and CCR1 were dichotomized by median value and differences in survival between groups were evaluated by the log-rank test.

\section{Results}

The assessment of mRNA expression revealed significant increases in levels of CCL3 and CCR1 in OSCC, compared with the controls $(\mathrm{P}<0.05)$ (Fig. 1). The expression of CCR5 in OSCC was not different to that of control samples (Fig. 1). Considering these data, we investigated the immunoexpression of CCL3 and CCR1 in neoplastic cells (parenchyma), 


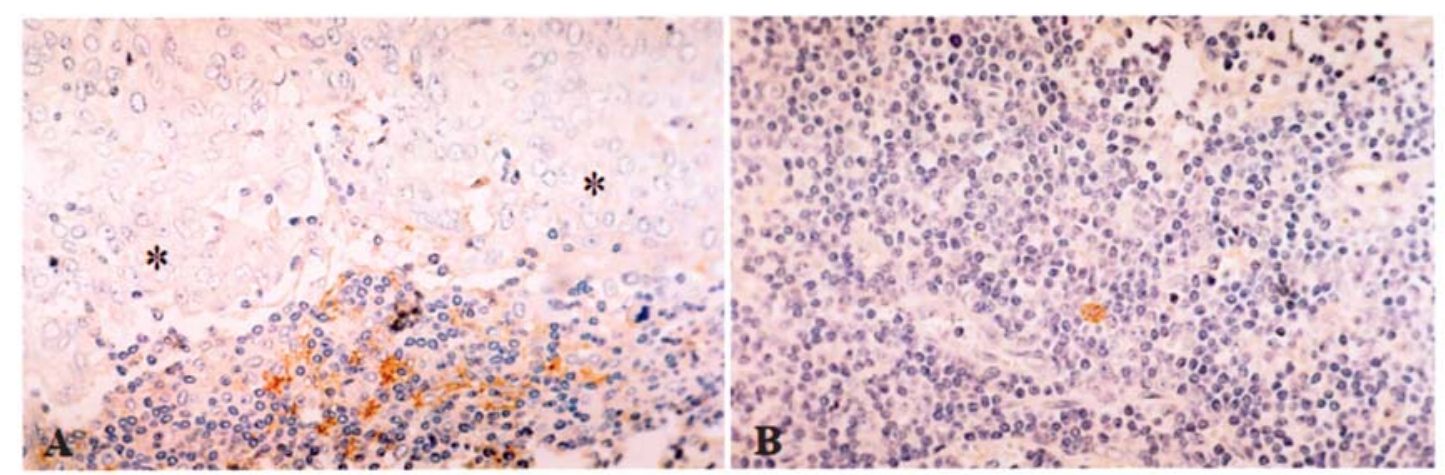

Figure 4. High expression of CCL3 in the metastatic cervical lymph node (A) and few CCL $3^{+}$nodal cells in the non-metastatic cervical lymph node (B) of a patient with oral squamous cell carcinoma (OSCC). The asterisks $(*)$ represent metastatic neoplastic cells in the lymph node. Immunohistochemical staining, original magnification $\mathrm{x} 400$ (A and B).
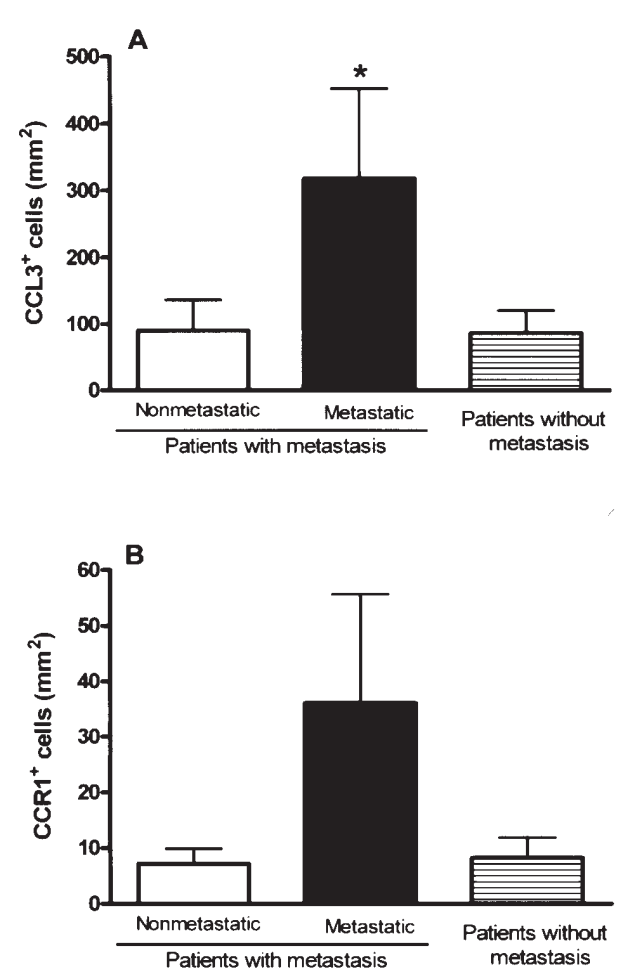

Figure 5. Densities of CCL3 (A) and CCR1 (B) positive cells in the lymph node of patients with oral squamous cell carcinoma (OSCC) without cervical lymph node metastasis and patients with cervical lymph node metastasis. Results are expressed as means of CCL3 and CCR1 positive cells per $\mathrm{mm}^{2} \pm \mathrm{SD}$ ( $n=10$ for lymph node samples from patients with cervical metastasis, $n=7$ for lymph nodes samples from patients without cervical metastasis). ${ }^{*} \mathrm{P}<0.05$ when compared to non-metastatic lymph nodes of the same patients (Wilcoxon test).

inflammatory/immune cells (stroma) in primary OSCC and in metastatic and non-metastatic lymph node tissues.

In OSCC, both $\mathrm{CCL}^{+}{ }^{+}$and $\mathrm{CCR} 1^{+}$cells were scattered relatively evenly throughout the tumoral parenchyma and stroma (Fig. 2). The percentages of $\mathrm{CCL}^{+}$and $\mathrm{CCR} 1^{+}$ neoplastic cells (parenchyma) were slightly higher in OSCC with lymph node metastasis when compared with OSCC without lymph node metastasis, but no statistical significance was achieved $(\mathrm{P}=0.32$ and $\mathrm{P}=0.16$, respectively) (Fig. 3A and C). Similarly, in OSCC stroma, we observed a tendency for OSCC with lymph node metastasis to have a high percentage of $\mathrm{CCL}^{+}(\mathrm{P}=0.5)$. The percentage of $\mathrm{CCR} 1^{+}$cells was similar in patients with or without metastasis (Fig. 3B and D).

The density of CCL3 ${ }^{+}$nodal cells was significantly higher in metastatic lymph nodes when compared with non-metastatic lymph nodes of the same patients $(\mathrm{P}=0.013)$ (Fig. 4 and 5). Our results also showed that the number of $\mathrm{CCL}^{+}$nodal cells per $\mathrm{mm}^{2}$ in metastatic lymph nodes was higher than in nonmetastatic lymph nodes in 9 out of the 10 patients evaluated. Additionally, the number of CCL $3^{+}$nodal cells was higher in the metastatic lymph node when compared with non-metastatic lymph node of patients that had no metastasis; however, this difference was not statistically significant ( $\mathrm{P}=0$.47) (Fig. 5).

The density of $\mathrm{CCR} 1^{+}$nodal cells was higher in metastatic lymph nodes when compared with non-metastatic lymph nodes of the same patients and with non-metastatic lymph nodes of patients that did not have metastasis; but no statistically significant difference was observed. The number of CCL $3^{+}$ nodal cells was higher than $\mathrm{CCR} 1^{+}$for all groups of patients, with the $\mathrm{CCR}^{+}{ }^{+}$cell population representing $\sim 10 \%$ of the total of CCL $3^{+}$cells. The percentages of CCL3 and CCR 1 positive cells were almost identical in non-metastatic lymph nodes of patients that had metastasis and lymph nodes of patients without metastasis (Fig. 5). In all specimens of metastatic lymph nodes, $\mathrm{CCL} 3^{+}$and $\mathrm{CCR} 1^{+}$metastatic tumor cells were observed in variable proportions (mean of $12 \%$ and $1.4 \%$, respectively).

With regard to the last follow-up, mean survival was 79 months $(95 \% \mathrm{CI}=60-97)$. Mean survival rate of patients with OSCC without lymph node metastasis was 95 months $(95 \%$ $\mathrm{CI}=63-126)$ and of patients with OSCC with lymph node metastasis was 56 months (95\% CI=31-80).

For survival analysis, CCL $3^{+} / \mathrm{CCR} 1^{+}$cells in parenchyma and $\mathrm{CCL}^{+} / \mathrm{CCR} 1^{+}$cells in stroma were dichotomized by median values (high and low groups). A log-rank test showed no difference in survival between CCL3 or CCR1 groups $(\mathrm{P}=0.31 / \mathrm{P}=0.50$ and $\mathrm{P}=0.55 / \mathrm{P}=0.68$, respectively). However, when considering CCL3 in the parenchyma, the mean survival rate for the patients with high $\mathrm{CCL}^{+}$cell percentage was lower (68 months) than for those with low $\mathrm{CCL}^{+}$cell percentage ( 83 months). In contrast, in stroma, the mean 
A

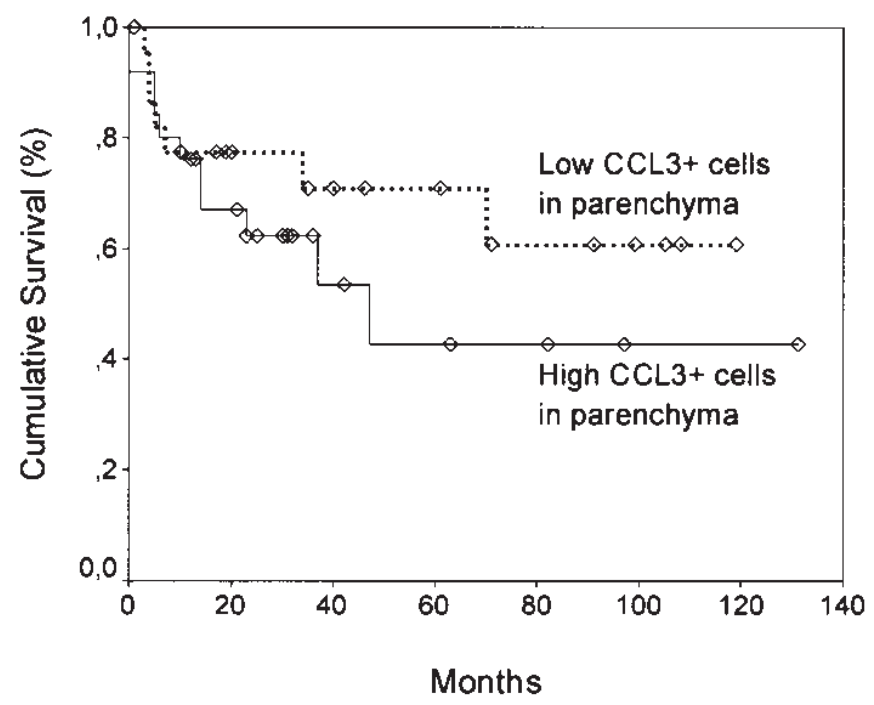

B

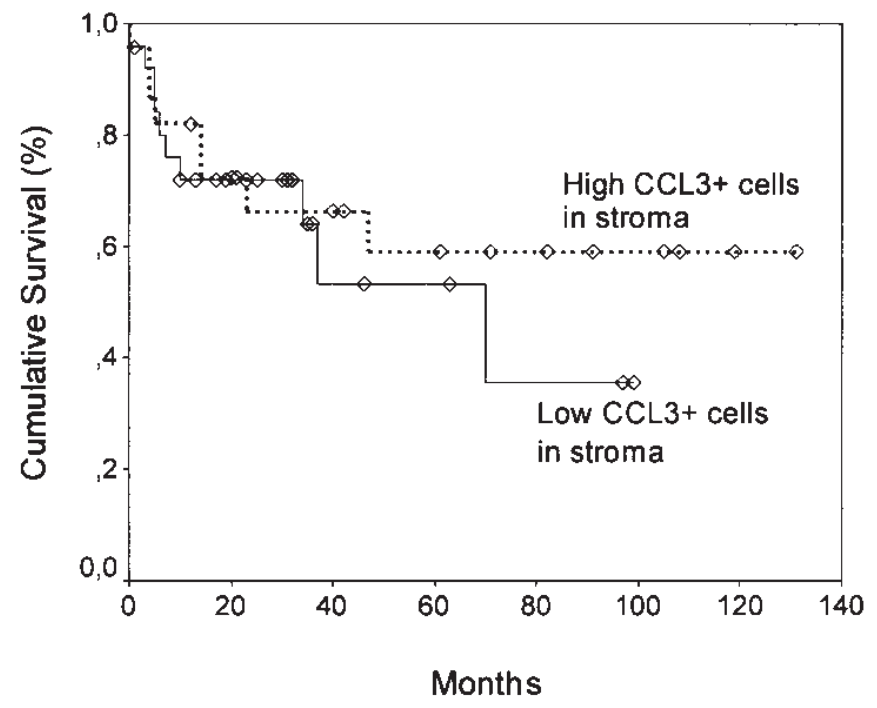

Figure 6. Kaplan-Meier survival curves, according to density status of CCL3 in parenchyma (A) and stroma (B) in primary OSCC.

survival rate for the patients with high $\mathrm{CCL}^{+}$cell percentage was higher (84 months) than for those with low CCL3 ${ }^{+}$cell percentage (56 months) (Fig. 6). Considering the CCR1+ cells in the parenchyma and in the stroma, the mean survival rate was similar in both high and low CCR1 groups.

\section{Discussion}

Oral squamous cell carcinoma (OSCC) is characterized by a high rate of metastasis in the cervical lymph node and this represents the most important survival-limiting factor for patients $(6,10,26)$. Considering this main spread of OSCC via neoplastic cells, the possible role of chemokines and their receptors, as important systems to determine the directional migration of tumor cells into lymph nodes has been reported (6,10-13). However, it is still not clear whether the chemokines and their receptors are involved in tumor metastasis or, conversely, whether they contribute to enhancing innate/ specific host immunity against tumor initiation and dissemination $(3,15)$.

We investigated the mRNA for the CCR5 and CCR1 ligand CCL3 in OSCC. We observed significant increases in mRNA of CCR1 and CCL3, but not of CCR5 in OSCC compared with control samples. According to our data, macrophages from patients with breast cancer show an up-regulation of CCR1 and down-regulation of CCR5 expression, while the opposite is observed in cells obtained from patients without cancer (16). We then investigated the protein expressions of CCL3 and CCR1 in the parenchyma and stroma of OSCC and in metastatic and non-metastatic lymph node tissues. Our results demonstrated the overexpression of the CCL3 chemokine in metastatic lymph nodes, when compared with non-metastatic lymph nodes of the same patients, and with non-metastatic lymph nodes of patients without metastasis. In addition, a greater percentage of $\mathrm{CCR} 1^{+}$neoplastic cells was observed in the OSCC with lymph node metastasis than in those without lymph node metastasis. A possible hypothesis to explain the increased expression of CCL3 in the metastatic lymph nodes, observed by us, could be the increased drainage of tumoral antigens to these sites, which may contribute to the lymph node reactivity and, consequently, CCL3 overexpression. In this context, this chemotactic gradient in lymph node tissues may contribute to metastasis, considering the hypothesis that oral cancer cells may be responsive to chemokines, as previously shown $(3,4,6-8,12,13)$.

In contrast, significant differences were not observed in the absolute or relative numbers of CCR1 positive cells in OSCC stroma. Moreover, no difference in mean survival rate was observed for those patients with high and low $\mathrm{CCR} 1^{+}$cell number in the parenchyma and in the stroma.

In OSCC parenchyma, despite the similar numbers of CCL3 positive cells in patients with and without metastasis, the percentage of these cells was slightly higher in patients with metastatic lymph nodes. Remarkably, the mean survival rate for the patients with high $\mathrm{CCL}^{+}$cell percentage in the parenchyma was lower (68 months) than for those with low $\mathrm{CCL}^{+}$cell percentage ( 83 months). The precise mechanisms underlying these effects are not yet clear; however, the CCL $3^{+}$ tumor cells may represent metastatic subclones with an advantage for detaching and spreading. Previous results have associated the CCL3 with tumor progression on the basis of these effects on angiogenesis and metalloproteinase expression (15). In this setting, since angiogenesis and matrix degradation are presumed to be crucially required for tumor progression, these subclones with the ability to produce CCL3 might induce changes in tumoral stroma that may favor metastasis.

On the other hand, the numbers and types of cells that make up the leukocyte which infiltrate in tumors are related to the local production of chemokines by both the tumor and stromal cells (3) and may be important for stimulating the host immune response against tumor cells $(3,25)$. The CCL3 chemokine may regulate the chemotaxis and tumoricidal activation of leukocytes in immunocompetent mice and may be an important mediator of tumor growth and associated inflammation $(16,25,27)$. Nakashima et al (25) suggest that tumor cells transfected with the CCL3 gene might be useful as 
an effective therapy for the treatment of certain tumors. It is worth noting that in our study, the survival analysis demonstrated that those patients with a lower number of $\mathrm{CCL}^{+}$cells in the stroma demonstrated a tendency for worse prognosis than patients with high $\mathrm{CCL}^{+}{ }^{+}$cell counts. Possibly, the low secretion of the CCL3 chemokines by stromal cells in the local microenvironment of the OSCC may reflect a failure to recruit tumoricidal monocytes (16). According to these results, we previously demonstrated a failure of mast cell migration in OSCC and a tendency for a worse prognosis in patients with lower numbers of tryptase ${ }^{+}$and c-kit ${ }^{+}$mast cells (28).

A recent report provided evidence that the chemokine receptor, CCR1 and its ligand, CCL3, might have multiple roles in tumorigenesis, affecting both tumor initiation and progression (15). These authors (15) demonstrated that whereas hepatocellular carcinoma occurred more frequently in both CCL3- and CCR1-deficient mice, compared with the wild-type controls, tumor burden (foci number and proportion of the organ occupied by tumor) was dramatically reduced in the former mice.

Our data suggest that the CCL3/CCR 1 system may be associated with lymph node metastasis in OSCC. Moreover, we found that the CCL3/CCR1 axis might act to stimulate the host inflammatory/immune response against tumor. Considering these results and in agreement with the findings of Yang et al (15), we suggest that the CCL3/CCR1 system might have multiple and opposite functions in tumorigenesis. The investigation of mechanisms underlying organ-specific metastasis and local invasion may lead to the development of therapy for the control of disseminated tumor spread or disease initiation.

\section{Acknowledgements}

The authors thank Araújo Jorge Hospital, Association of Cancer Combat of Goiás, Goiânia, Brazil. This study was supported by grants (401305/2005-8) from Conselho Nacional de Desenvolvimento Científico e Tecnológico (CNPq), Brazil and Fundação de Apoio à Pesquisa (FUNAPE), Goiânia, Brazil.

\section{References}

1. Baggiolini M: Chemokines and leukocyte traffic. Nature 392: 565-568, 1998.

2. Zlotnik A and Yoshie O: Chemokine a new classification system and their role in immunity. Immunity 12: 121-127, 2000.

3. Balkwill F: Cancer and the chemokine network. Nat Rev Cancer 4: 540-550, 2004.

4. Homey B, Muller A and Zlotnik A: Chemokines: agents for the immunotherapy of cancer? Nat Rev Immunol 2: 175-184, 2002.

5. Kunkel EJ and Butcher EC: Chemokines and the tissue-specific migration of lymphocytes. Immunity 16: 1-4, 2002.

6. Muller A, Sonkoly E, Eulert C, et al: Chemokine receptors in head and neck cancer: association with metastatic spread and regulation during chemotherapy. Int J Cancer 118: 2147-2157, 2006.

7. Liotta LA: An attractive force in metastasis. Nature 410: 24-25, 2001.
8. Muller A, Homey B, Soto H, et al: Involvement of chemokine receptors in breast cancer metastasis. Nature 410: 50-56, 2001.

9. Zlotnik A: Chemokines in neoplastic progression. Semin Cancer Biol 14: 181-185, 2004

10. Almofti A, Uchida D, Begum NM, et al: The clinicopathological significance of the expression of CXCR4 protein in oral squamous cell carcinoma. Int J Oncol 25: 65-71, 2004.

11. Delilbasi CB, Okura M, Iida S and Kogo M: Investigation of CXCR4 in squamous cell carcinoma of the tongue. Oral Oncol 40: 154-157, 2004.

12. Uchida D, Begum NM, Almofti A, et al: Possible role of stromal-cell-derived factor-1/CXCR4 signaling on lymph node metastasis of oral squamous cell carcinoma. Exp Cell Res 290: 289-302, 2003.

13. Uchida D, Begum NM, Tomizuka Y, et al: Acquisition of lymph node, but not distant metastatic potentials, by the overexpression of CXCR4 in human oral squamous cell carcinoma. Lab Invest 84: 1538-1546, 2004.

14. Lu P, Nakamoto Y, Nemoto-Sasaki Y, et al: Potential interaction between CCR1 and its ligand, CCL3, induced by endogenously produced interleukin-1 in human hepatomas. Am J Pathol 162: 1249-1258, 2003.

15. Yang X, Lu P, Fujii C, et al: Essential contribution of a chemokine, CCL3, and its receptor, CCR1, to hepatocellular carcinoma progression. Int J Cancer 118: 1869-1876, 2006.

16. Nath A, Chattopadhya S, Chattopadhyay U and Sharma NK: Macrophage inflammatory protein (MIP) 1alpha and MIP1beta differentially regulate release of inflammatory cytokines and generation of tumoricidal monocytes in malignancy. Cancer Immunol Immunother 55: 1534-1541, 2006.

17. Lee SC, Brummet ME, Shahabuddin S, et al: Cutaneous injection of human subjects with macrophage inflammatory protein- $1 \alpha$ induces significant recruitment of neutrophils and monocytes. J Immunol 164: 3392-3401, 2000.

18. Maghazachi AA, al-Aoukaty A and Schall TJ: C-C chemokines induce the chemotaxis of NK and IL-2-activated NK cells. Role for G proteins. J Immunol 153: 4969-4977, 1994.

19. Miyazaki D, Nakamura T, Toda M, Cheung-Chau KW, Richardson RM and Ono SJ: Macrophage inflammatory protein$1 \mathrm{alpha}$ as a costimulatory signal for mast cell-mediated immediate hypersensitivity reactions. J Clin Invest 115: 434-442, 2005.

20. Rot A, Krieger M, Brunner T, Bischoff SC, Schall TJ and Dahinden CA: RANTES and macrophage inflammatory protein $\alpha$ induce the migration and activation of normal human eosinophil granulocytes. J Exp Med 176: 1489-1495, 1992.

21. Schall TJ, Bacon K, Camp RD, Kaspari JW and Goeddel DV: Human macrophage inflammatory protein alpha (MIP-1 alpha) and MIP- 1 beta chemokines attract distinct populations of lymphocytes. J Exp Med 177: 1821-1826, 1993.

22. Sozzani S, Luini W, Borsatti A, et al: Receptor expression and responsiveness of human dendritic cells to a defined set of CC and CXC chemokines. J Immunol 159: 1993-2000, 1997.

23. Taub D, Dastych J, Inamura N, et al: Bone marrow-derived murine mast cells migrate, but do not degranulate, in response to chemokines. J Immunol 154: 2393-2402, 1995.

24. Taub DD, Conlon K, Lloyd AR, Oppenheim JJ and Kelvin DJ: Preferential migration of activated CD4+ and CD8+ T cells in response to MIP-1 $\alpha$ and MIP-1B. Science 260: 355-358, 1993.

25. Nakashima E, Oya A, Kubota Y, et al: A candidate for cancer gene therapy: MIP-1 $\alpha$ gene transfer to an adenocarcinoma cell line reduced tumorigenicity and induced protective immunity in immunocompetent mice. Pharm Res 13: 1896-1901, 1996.

26. Massano J, Regateiro FS, Januario G and Ferreira A: Oral squamous cell carcinoma: review of prognostic and predictive factors. Oral Surg Oral Med Oral Pathol Oral Radiol Endod 102: 67-76, 2006.

27. Singh RK and Fidler IJ: Synergism between human recombinant monocyte chemotactic and activating factor and lipopolysaccharide for activation of antitumor properties in human blood monocytes. Lymphokine Cytokine Res 12: 285-291, 1993.

28. Oliveira-Neto HH, Leite AF, Costa NL, et al: Decrease in mast cells in oral squamous cell carcinoma: Possible failure in the migration of these cells. Oral Oncol 43: 484-490, 2007. 